\title{
Land cover as a factor affecting the structure and modifying the dynamics of a landscape system
}

\begin{abstract}
The key objective of the study is to analyse structural characteristics of the landscape from the viewpoint of the structure's durability, characteristics and speed of change. The research focused on the area surrounding Płock.

In the analysed period (1987-2010) slight changes were detected with regard to the land cover, though they were significant in terms of the natural environment. No single dominant process determining land cover change was identified. Fluctuations prevailed (producing a slightly different picture in each microregion), with a fixed pattern maintained. Distribution, shape and spatial location of land cover types are only partly determined by land lie and habitat quality. Fragmentation of the terrain is relatively high, which reflects intense land use, at the same time indicating opportunities to preserve the wildlife and vegetation typical for agrocenoses.
\end{abstract}

\section{Keywords}

Land use - landscape structure - land cover classification - landscape metrics $\cdot$ landscape dynamics

(C) University of Warsaw - Faculty of Geography and Regional Studies

\author{
Jerzy Solon ${ }^{1}$, Jerzy Lechnio \\ 'Institute of Geography and Spatial Organization \\ Polish Academy of Science \\ e-mail: j.solon@twarda.pan.pl \\ 2Department of Geoecology \\ Institute of Physical Geography \\ Faculty of Geography and Regional Studies \\ University of Warsaw \\ e-mail: jrlechni@uw.edu.pl \\ Received: 2 November 2013 \\ Accepted: 12 December 2013
}

\section{Introduction}

Analysis of structural landscape characteristics constitutes the foundation of geoecological research. Under a general approach, it is related to the assessment of patch configuration and composition, as well as to land use classification and analysis (Griffiths et al. 2000), which have been recently performed mainly based on digital images of the surveyed land.

The popularity of such studies is enhanced by easy access to materials in the form of satellite and aerial data and data processing technology development. Information obtained in this manner is widely used due to potentially easy processing and operation in a variety of scales.

This is of particular importance for landscape research, since natural systems are characterized by a wide range of spatial features, speed change and organization. The assessment focuses mainly on the analysis of landscape composition and configuration and spatial interrelations and trends regarding structural changes in time, which may also indicate their relation to landscape dynamics (Richling, Lechnio 2005; 2012; Turner 1989; Uuemaa et al. 2009; Walz 2011).

Land use and cover is the key element, relatively easily identifiable, both in terms of value and spatial range (Gulinck et al. 2001). Materials in the form of satellite and aerial images are easily available. Please note, though, that their use is limited by spatial and spectral resolution. Potential lack of precision and simplified analysis resulting from their use may cause incorrect interpretation of borders, and therefore imprecise assessment of a landscape mosaic's spatial range.

Diversity, connectivity, fragmentation, anisotropy and changes of the landscape mosaic over time (identified with evaluation of its dynamics), in most cases examined by the analysis of time series and evaluation of detected changes, lie within the scope of landscape structure evaluation, including biodiversity (Aaviksoo 1995; McGarigal, Tagil, Cushman 2009; Turner et al. 1989; Uuemaa et al. 2009; Solon 2002).

Please note that, despite a wide scope of possible analysis regarding landscape structure evaluation, such analyses are always based on the assessment of spatial characteristics, regardless of their subsequent interpretation. This in turn indicates the necessity of using tools, approaches and methods allowing the most precise assessment possible of currently existing objects, with full awareness of effects of spatial scale of the analyses applied, image resolution and classification of landscape mosaic objects (Mander et al. 2005; Piorr 2003; Richling, Lechnio 2012). If landscape metrics are used, the selection of relevant measures with characteristics and number fitting the purpose of the evaluation is of crucial importance. Using too many metrics may cause problems when developing correct and precise assessment (Uuemaa et al. 2009; Walz 2011).

\section{Research assumptions and methodologies}

The purpose of the study is to analyse land use near Płock to provide the basis for the description of structural characteristics of the landscape in terms of durability, and nature and speed of change (Fig. 1).

Microregions (Richling, Malinowska, Szumacher 2012) provided the reference field, with the use of the patches of mosaic land use pattern as the key element determining diversification. 


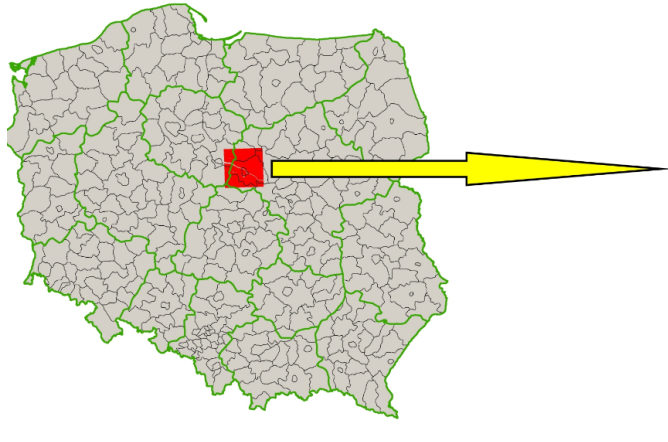

Figure 1. The study area localisation

The work is the continuation of former research carried out in the area (Lechnio 2005; Richling, Malinowska, Lechnio 2005; Richling, Malinowska, Szumacher 2012; Solon 2005).

The organization of the research involved a number of stages including:

1. Defining the time horizon for the analyses, indicating the number of diagnostic periods so that the resultant comparative data ensure desirable diagnostic values;

2. Selecting available digital images in terms of quality, spatial and spectral resolution;

3. Classifying land use and cover for all diagnostic periods determined in stage 1 ;

4. Performing analyses of landscape structure evaluation for each diagnostic period and comparing them;

5. Drawing conclusions regarding changes or durability of the landscape structure.

Since the surveyed area has been highly urbanized, the analysed period covers $25-30$ years to allow the determination of the usage structure "typical" for conditions before 1989 and changes resulting from the economic transformation and growth.

Three moments have been determined corresponding to these periods. LANDSAT ETM images (with $30 \mathrm{~m}$ resolution) originating from $1987.08 .23,2000.08 .02$ and 2010.09 .23 , i.e. from the intense vegetation, although post-harvest season, have been adopted as the key material.

All images included in the research area $\left(3,600 \mathrm{~km}^{2}\right)$ had zero cloud cover, which made their further processing much easier.

eCognition Developer 64 v. 8.64 was used for classification. In this case, multiresolution bottom-up segmentation was applied (Benz et al. 2004).

Under this approach, segments are treated as the basic calculation units. Object analysis allows the separation of such basic structures thanks to the use of optimization procedures that facilitate the minimisation of local image heterogeneity. The object resulting from the segmentation represents a pixel or a pixel group uniform in terms of determined characteristics (colour, intensity, texture), at the same time including surrounding features that make the object stand out from the background Unlike the "traditional" classification based on values of individual pixels (pixel by pixel classification), the method allows actual identification of the image structure, which improves the precision of separating homogenous pixel groups, in this case belonging to the same usage class (Blaschke et al. 2001; Hay et al. 1997).

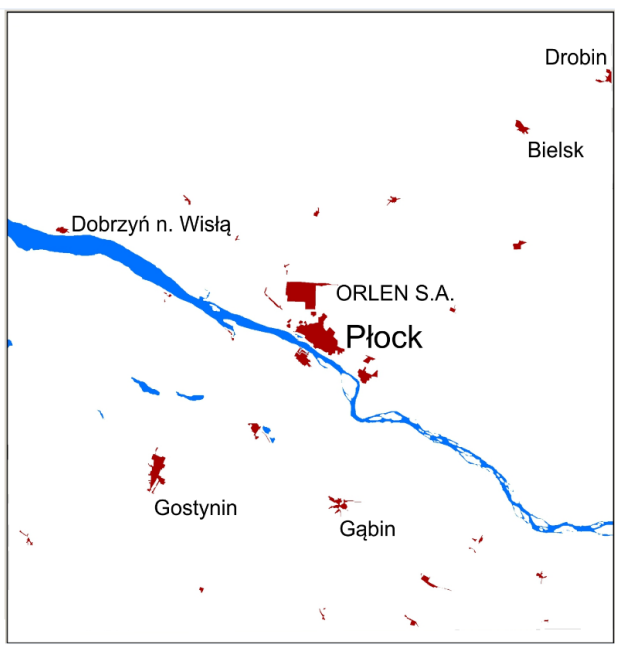

Key analyses of landscape spatial structure were performed with ArcView 3.3. software using the existing extensions. When determining the orientation of the longest axis of the patches, Longest Straight Line v.1.3a (Jenness Enterprises) was used, while basic landscape metrics were calculated with PatchAnalyst 3.1 .

The results were further processed with relevant statistical and graphic software. The similarity of the spatial structure of microregional units (at the same time constituting separate landscape units) was determined with Euclid distance, using Ward's grouping method. The following characteristics of the spatial structure (landscape metrics) were used for this purpose: NUMP (Number of Patches), MPS (Mean Patch Size), MEDPS (Median Patch Size), PSCOV (Patch Size Coefficient of Variance $=$ PSSD $\left./ M^{*}{ }^{*} 100\right)$, ED (Edge Density), MPE (Mean Patch Edge), MSI (Mean Shape Index), AWMSI (Area-Weighted Mean Shape Index), MPAR (Mean Perimeter-Area Ratio), MPFD (Mean Patch Fractal Dimension), AWMPFD (Area Weighted Mean Patch Fractal Dimension).

In order to characterize the fragmentation of the field complex, four secondary indicators were used:

- NUMP_ratio = NUMP(not aggregated)/ NUMP(aggregated); determining the average number of individual fields constituting one field complex;

- edge_ratio $=\mathrm{TE}($ not aggregated $) / \mathrm{TE}($ aggregated $)$;

determining how many times longer individual borders of small fields are than the external border of the entire field complex;

- inner_edge $\%=[\mathrm{TE}($ not aggregated $)-\mathrm{TE}($ aggregated $)]$ / TE(aggregated); indicating the share of borders in an individual field out of the total borders in the field complex; at the same time, it approximates the share of boundary strips, which can be interpreted as an indicator of the potential biological diversity within field complexes;

-AWMSI_ratio = AWMSI (aggregated) / AWMSI (not aggregated); approximating differences in irregularity of field complex shape; the index interpreted for consecutive periods provides approximate information on processes equalizing borders between arable land and other land cover types.

Results

Land cover classification

The classification of land cover was carried out with the multispectral image classification and multiresolution bottom- 

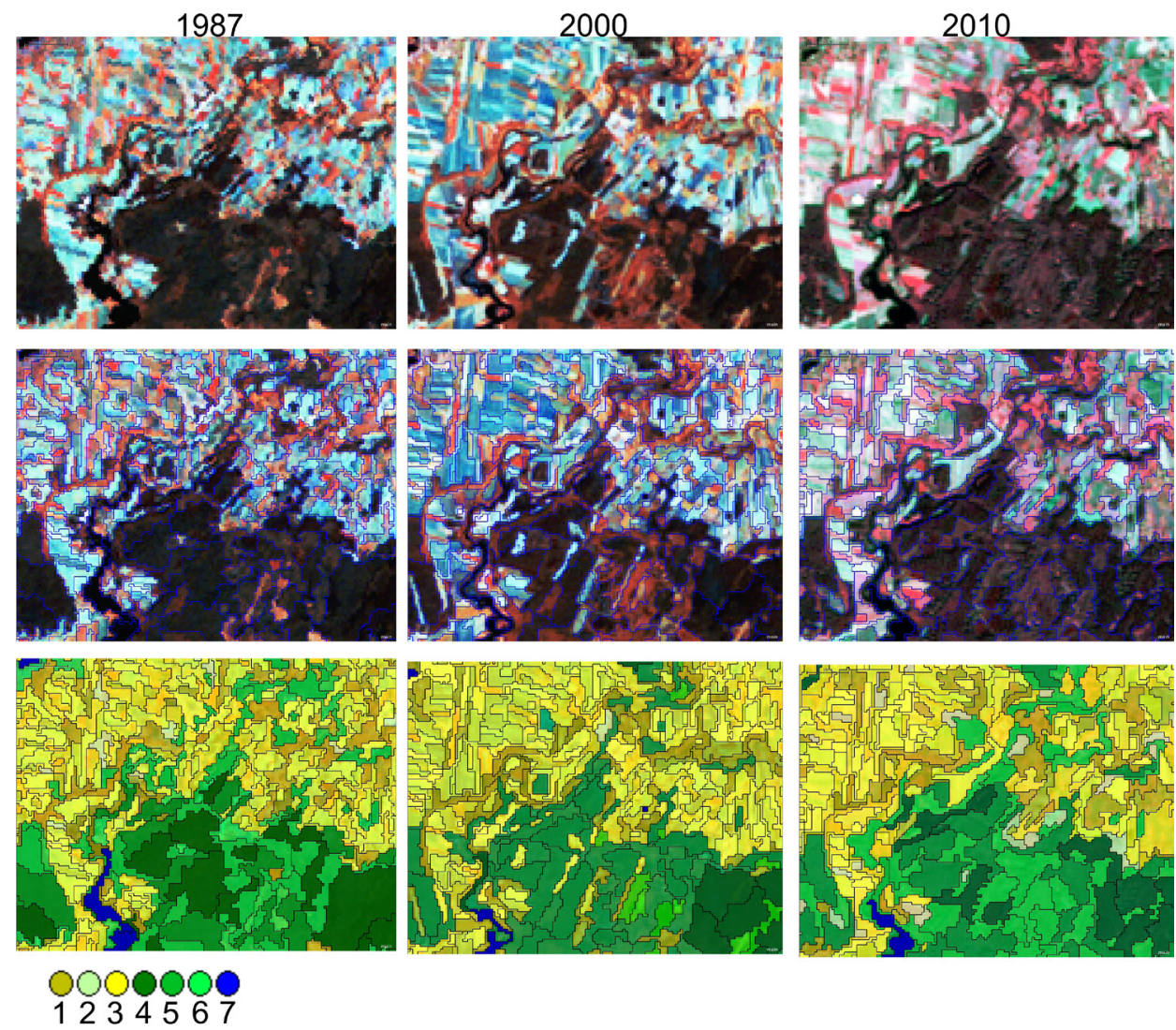

Figure 2. Land cover mosaic segments and results of classification as at 1987.08.23, 2000.08.02 and 2010.09.23 (developed with Landsat images from: http://glcfapp.glcf.umd.edu:8080/esdi). 1 - grasslands with shelterbelts, 2 - pastures, grasslands, 3-arable land, 4 - coniferous forest, 5-mixed forest, 6 - deciduous forest, 7 - lakes and rivers

up segmentation method (Benz et al. 2004, eCognition Developer 8.64.0 User Guide 2010).

The segmentation algorithm in eCognition software allows the identification of subsequent pixels and their combination into objects based on relative uniformity criteria, including spectrum characteristics and shape. The scale parameter selecting option allows the identified segments to be referred to the actual existing borders. Such a solution would also be important for further results analysis, since it was highly probable that key landscape mosaic segments closely reflect the system of actually existing forms of land cover (forest, field, pasture mosaic patches, water bodies and courses, complexes of buildings and structures), in particular those larger than the resolution of the used images.

In the first stage, the resultant landscape mosaic segments identified the uniform land cover complexes (Fig. 2). In the subsequent stage, they were classified within eighteen classes, and then generalized into ten classes. The produced distribution of "basic" landscape mosaic patches for each period underlay further analysis. The classification results are presented in Table 1.

In the classification development stage, the initially separated segments were referred to manually defined land cover classes. For this purpose, materials provided by Państwowe Gospodarstwo Leśne Lasy Państwowe (State Forests) were used with data originating from the field inventory corresponding to the dates of the images. At the same time, for each image, vegetation indexes and indicators were calculated, which, combined with the reference materials, allowed subsequent automated generalization of the produced image.
Analysis of land cover changes

Land cover changes detected in the analysed period were small in terms of figures, but important in terms of nature (Fig. 3). Several change patterns have been observed, specific to each cover class.

In the years 1987-2010 the share of arable land decreased in nearly all microregions. By the year 2000 , in those with a high share of fields it had initially increased, while in those where the share had been initially small, it had visibly dropped. In the years 2000-2010, it decreased in nearly all microregions.

The acreage of forests decreased in the years 1987-2000 in nearly all spatial units, while in the years $2000-2010$ the share of forest increased. A combined analysis of both periods indicated that in the microregions with an initial forest share lower than $25 \%$, it further decreased, while in other units the afforestation level grew, although the growth was not evenly distributed in time and space, with the maximum increment for those units with initial cover between $35-50 \%$.

The third pattern included open grassland, pastures and meadows. In the years 1987-2000 their acreage somewhat decreased, to grow in almost all units in the subsequent period to a level exceeding their initial share.

Grassland encroached by trees demonstrated yet another pattern since, following a strong initial growth in share, there was a visible drop in the years 2000-2010, although the resulting acreage is still higher than in 1987.

Changes in the last two land cover classes require additional interpretation. The initial drop in the share of open grassland and increase in the share of grassland with trees seems to be an 
Table 1. Statistical characteristics of the classification results as at 1987, 2000 and 2010

\begin{tabular}{|c|c|c|c|c|c|c|}
\hline Year & \multicolumn{2}{|c|}{1987} & \multicolumn{2}{c|}{2000} & \multicolumn{2}{c|}{2010} \\
\hline Land use & $\begin{array}{c}\text { Number of } \\
\text { segments }\end{array}$ & $\begin{array}{c}\text { \% of total } \\
\text { area }\end{array}$ & $\begin{array}{c}\text { Number of } \\
\text { segments }\end{array}$ & $\begin{array}{c}\text { \% of total } \\
\text { area }\end{array}$ & $\begin{array}{c}\text { Number of } \\
\text { segments } \\
\text { area }\end{array}$ \\
\hline Grasslands & $\mathbf{1 2 4 9 4}$ & $\mathbf{1 5 . 2 2}$ & $\mathbf{1 2 2 7 0}$ & $\mathbf{1 6 . 3 5}$ & $\mathbf{1 2 7 4 5}$ & $\mathbf{1 9 . 8 9}$ \\
\hline with shelterbelts & 9018 & 11.95 & 10492 & 13.98 & 10167 & 16.27 \\
\hline pastures, grasslands & 3476 & 3.28 & 1778 & 2.37 & 2578 & 3.62 \\
\hline Agricultural land & $\mathbf{5 5 3 3 5}$ & $\mathbf{5 9 . 4 6}$ & $\mathbf{5 7 0 7 9}$ & $\mathbf{6 1 . 1 1}$ & $\mathbf{4 1 0 4 8}$ & $\mathbf{5 6 . 0 9}$ \\
\hline Forests & $\mathbf{1 2 3 1 8}$ & $\mathbf{2 2 . 4 3}$ & $\mathbf{8 8 9 2}$ & $\mathbf{1 9 . 1 7}$ & $\mathbf{7 0 3 6}$ & $\mathbf{2 0 . 3 2}$ \\
\hline coniferous & 1423 & 6.54 & 961 & 4.34 & 1277 & 6.96 \\
\hline mixed & 1808 & 4.35 & 6694 & 5.29 & 1458 & 4.60 \\
\hline deciduous & 9087 & 11.55 & 1237 & 9.53 & 4301 & 8.76 \\
\hline Lakes and rivers & $\mathbf{6 0 3}$ & $\mathbf{2 . 3 8}$ & $\mathbf{7 1 6}$ & $\mathbf{2 . 4 0}$ & $\mathbf{4 2 3}$ & $\mathbf{2 . 3 6}$ \\
\hline Built-up areas & $\mathbf{5 5 6}$ & $\mathbf{0 . 5 0}$ & $\mathbf{7 8 0}$ & $\mathbf{0 . 9 7}$ & $\mathbf{7 0 1}$ & $\mathbf{1 . 3 4}$ \\
\hline town structures & 412 & 0.43 & 624 & 0.26 & 534 & 0.94 \\
\hline rural buildings & 144 & 0.07 & 156 & 0.71 & 167 & 0.40 \\
\hline SUM & $\mathbf{8 1 3 0 6}$ & 100.00 & $\mathbf{7 9 7 3 7}$ & 100.00 & $\mathbf{6 1 9 5 3}$ & 100.00 \\
\hline
\end{tabular}
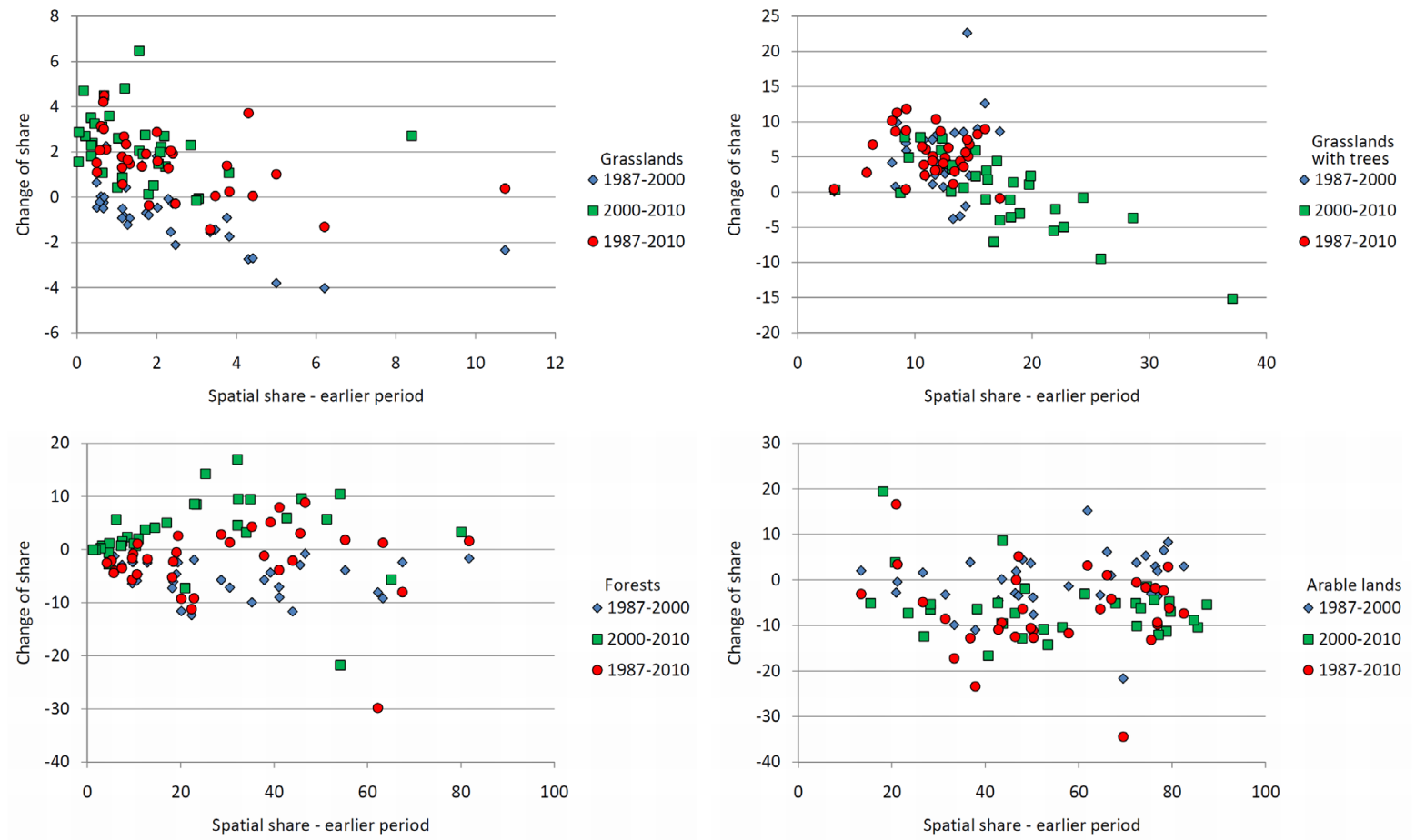

Figure 3. Changes in spatial share of grasslands, forests, and arable land in relation to the earlier period

effect of uncontrolled succession in unused meadows and old set-aside areas.

In the second period, some grassland encroached by trees (in particular, those in moist habitats) was reclassified to forest, while new areas occupied by "grassland encroached by trees" are related, at least to some extent, with the development of new single-family housing accompanied by trees planted around the houses.
Patch orientation

Patch orientation analysis is relatively infrequent (see e.g. Roo-Zielińska et al. 2007), although it produces interesting data. First of all, it allows a comparison of the diversity of abiotic conditions (expressed e.g. by orientation and location of geomorphological forms or potential vegetation) with actual land use, which indirectly indicates the role of natural conditions in the land use and indirectly measures human pressure exercised 


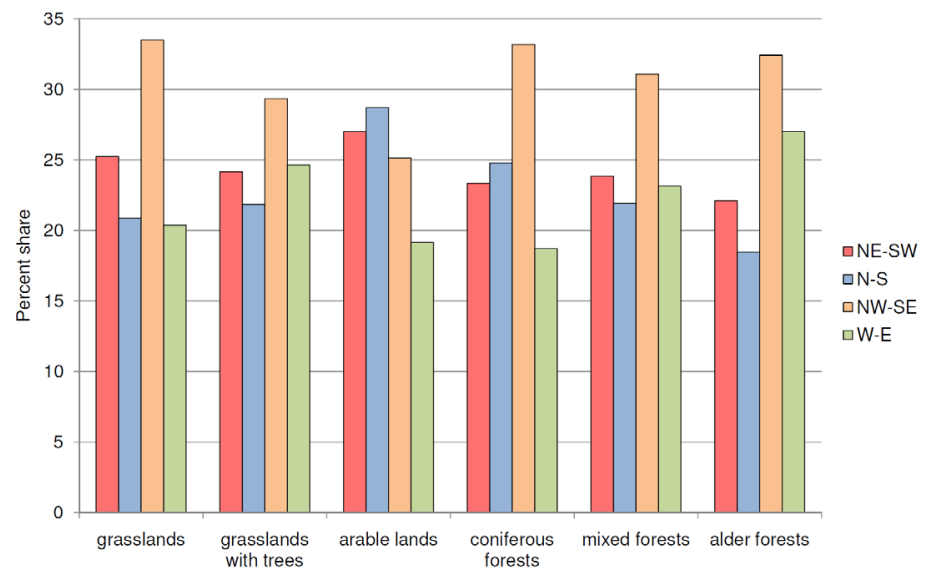

Figure 4. Percent share of different directions of the patch long axes for different types of land cover
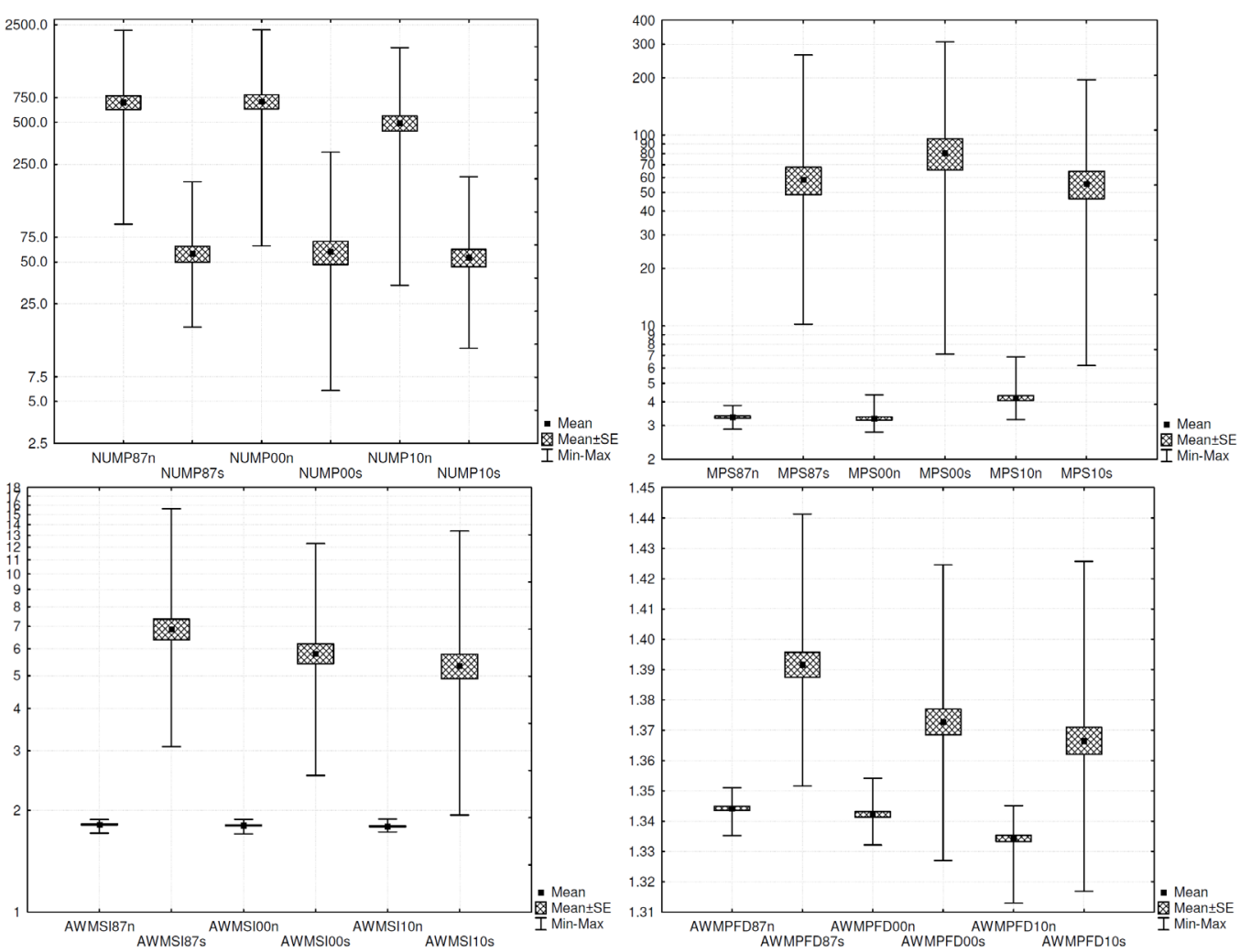

Figure 5. Comparison of chosen metrics for unaggregated and aggregated fields. Code description: NUMP - Number of Patches; MPS - Mean Patch Size (ha); AWMSI - Area-Weighted Mean Shape Index; AWMPFD - Area Weighted Mean Patch Fractal Dimension; 87 - year 1987; 00 - year 2000; 10 - year 2010; $n$ - unaggregated fields; s- aggregated fields (complexes)

on the landscape. Furthermore, it indicates the history of a given area, in particular for anthropogenic land cover forms, sometimes also assisting in the identification of historical property borders.

In the analysed area, all cases of patch orientation are represented with similar frequency, with the general impression of chaos, the absence of any order. A more detailed analysis, though, indicates some patch orientation patterns for each land cover class (Fig. 4). For coniferous forests (as for many other land cover types), NW-SE orientation prevails, arising from the past clear cutting practices. For mixed and deciduous forests, the long axis orientation frequency is similar, not as closely related to typological differences, but more to plot-cutting practices. Wet forests and woods (classified as alder forests) also demonstrate varied spatial orientation, but in this case, the shape and location of long axes is related to land lie and the presence of valleys and depressions.

Land lie has a similar effect on the spatial orientation of grassland and pastures, usually with NW-SE orientation; just a small portion follows the adjacent fields in this respect.

Field complexes demonstrate the most diversity in terms of long-axis orientation. WE-oriented patches are the least frequent (holding the last place in 20 out of 33 microregions) while those 

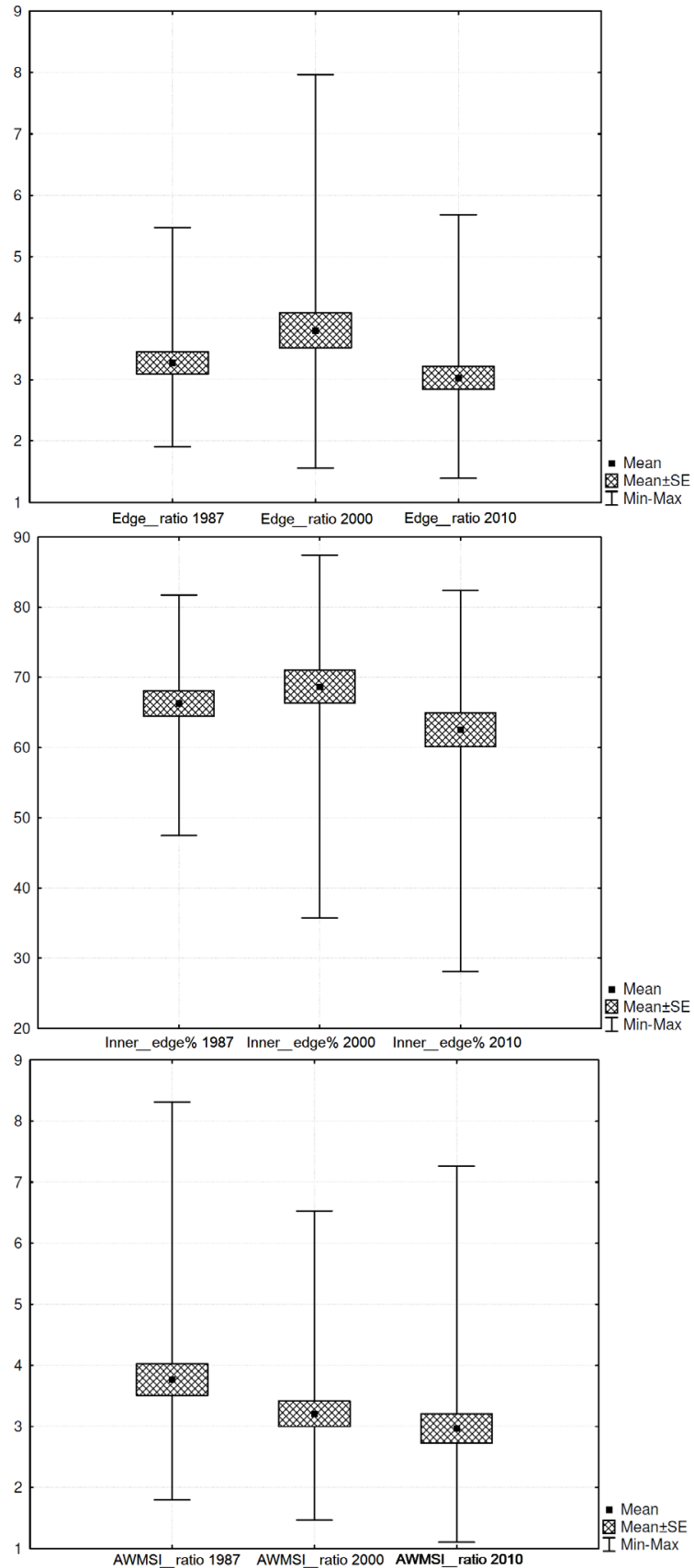

Figure 6. Temporal changes of field complex fragmentation metrics

with NS orientation are the most frequent (dominating in 15 regions and subdominating in five).

Please note that fields with specific orientation are not evenly distributed but form clear groups, in most cases corresponding to selected (aggregated) field complexes, usually one settlement unit (currently or historically).

\section{Spatial structure of fields}

Different natural conditions accompanying the existence of fields and demonstrated in land use have resulted in the individual character of each microregion. They are visible regardless of problems with clear interpretation of source materials and despite rapid land cover changes occurring in the years 1987-2010.
Individual microregions demonstrate significant differences in terms of the share of fields, field and complex size and shape. Overall the number of separate fields showed a decreasing tendency, and ranged from 93 to almost 23000 in 1987, from 65 to almost 23300 in 2000, being in the range of 34 to almost 16300 in 2010. A similar but less strong tendency is also visible when analysing the number of field complexes (Fig. 5).

MPS index (the average size of an unaggregated field) ranged in 1987 from 2.87 ha to 3.84 ha, in 2000 from 2.77 ha to 4.36 ha and in 2010 from 3.23 ha to 6.88 ha (Fig. 5). On average, for all years, in $53 \%$ of cases (referring to the number of elementary patches) it was below 3.5 ha and ranged from 3.5 to 4 ha for another $30 \%$.

For aggregated complexes, the average size per microregion ranged from-10 ha to 263 ha in 1987, from 7 ha to 309 ha in 2000 , and from 6 ha to 195 ha in 2010. Generally, for all terms together, in $58 \%$ of cases the average field complex size was lower than 50 ha and in $20 \%$ of cases it was over 100 ha. Usually, small individual fields are regular (rectangular) in shape, while complexes do not reproduce this shape and are irregular as a rule.

This is reflected in all shape metrics. For example, the AWMSI indicator for unaggregated fields ranged, overall, from 1.7 to 1.9 , while for aggregated complexes the range was 1.9 to 15.6. It is worth underlining that, for unaggregated fields, minimal, mean and maximal values are almost stable, while for complexes, minimal and mean values decreased (Fig. 6). A similar (but not the same) pattern of changes was characteristic for the AWMPFD indicator. For unaggregated fields it ranges from 1.313 to 1.355 , showing a decreasing tendency for minimal and mean values. The same indicator for aggregated complexes ranged from 1.317 to 1.442 , but in $93 \%$ of cases, it ranged from 1.34 to 1.44. A decrease of minimal and mean values also occurred (Fig. 5).

The number of individual fields within a complex ranged from approx. 4 to approx. 80 in 1987, and from 2 to 44 in 2010. The differences can be only partially related to actual spatial processes, since they may also arise from different interpretations of the analysed images. Nevertheless, regions (315.142.7, $315.143 .4,315.143 .5,318.713 .3$ ) with the highest number of individual fields in a complex are identifiable. At the same time, the share of arable land in these units is the highest.

The length of internal borders (i.e. boundary strips separating fields) and a variety of derivative measures constitutes an important characteristic. It is worth noting that when comparing the years 1987 and 2010 one can observe a decrease in all derivative metrics (edge_ratio, inner_edge $\%$ and AWMSI_ratio) and their statistical parameters (min, mean, max). This tendency was slightly reversed in the year 2000 , with an increase in the mean and maximal values of edge_ratio and inner_edge (Fig. 6).

The above indicators are not independent. Generally the relationships between them are non-linear. For all relationships of interest (NUMP ratio - edge ratio; NUMP ratio - inner edge\%; NUMP_ratio - AW WMSI_ratio) we can observe a very fast growth of the values of the dependent variable in the range of small values of the independent one. In the case of edge_ratio the fastest, near-linear growth is observed when the number of patches in the complex does not exceed 15 (Fig. 7). Moreover, even with as few as ten patches in a complex, internal borders account for approx. $70 \%$ of all borders, while with forty patches in a complex, their share exceeds $80 \%$.

\section{Conclusion}

Analysis of the spatial structure of land cover within the determined microregions allows the definition of similarities and differences between fragments of land and facilitates the 


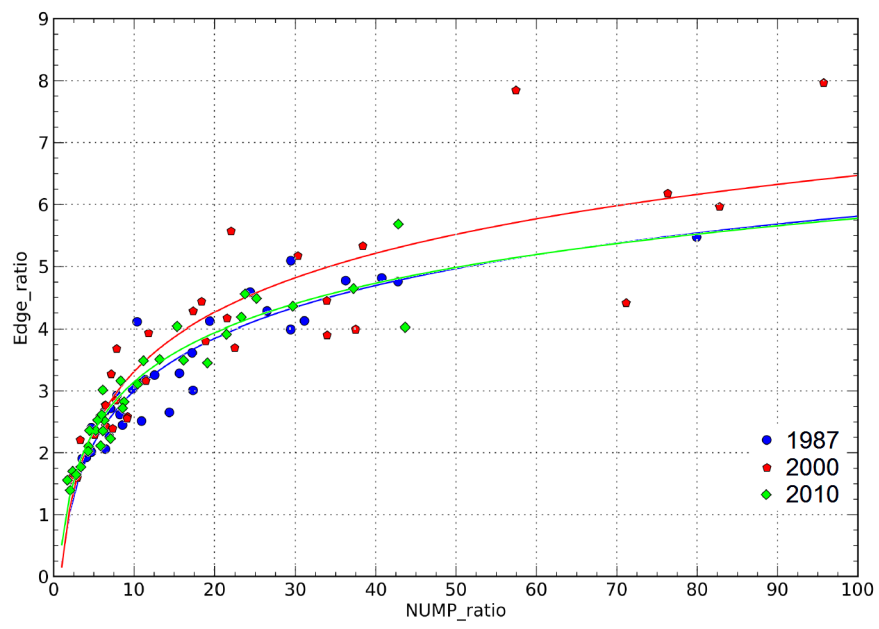

Figure 7. The relationship between the number of individual fields in the complex and the edge ratio of the field complexes. Natural Logarithm Model: $y=a+b^{\star} \operatorname{In}(x)$. Symbols: 1987 year - blue dots, $a=0.189331, b=1.221341$, correlation with the model $=0.9340 ; 2000$ year - red dots, $a=0.155784, b=1.371219$, correlation with the model $=0.8932 ; 2010$ year - green dots, $a=0.517371, b=1.142351$, correlation with the model $=0.9537$

identification and assessment of changes over time. Additionally, since the spatial structure can be treated as an image of energy cascades and matter flow (including energy and matter related to anthropogenic transformation - mainly landscape simplification see Wrbka et al. 1998), ratio analysis (with the use of landscape metrics) allows landscape characteristics to be identified and of the extent to which the landscape has been transformed to be assessed.

Despite uniform methods used to identify land cover changes in the years 1987-2010 please note that the used material differed in terms of technical parameters, which could cause certain errors (differences) in the classification of individual areas. Nevertheless, the spatial diversity of the changes and their relation to the previous status indicate that the key directions of land cover changes in the years 1987-2010 have been correctly defined.

Of course, Landsat scenes have a low resolution (ca $30 \mathrm{~m}$ ) so only (large-grained) trends of changes have been indicated.

The analysis indicates a number of general phenomena:

There is no single dominant and directed process determining land cover changes in the discussed area; fluctuations prevail (producing varying pictures in each microregion) with a certain pattern existing.

- There is a slow trend towards a reduction in the acreage of arable land, which is better visible in spatial units where fields do not constitute the dominant land cover form.
- Location, shape and orientation of separate land cover types are only partly determined by land lie and habitat quality. The relationship is strongest for moist forest and grassland and weakest for arable land.

- Land fragmentation, when determined based on the landscape mosaic divided into ten classes, is relatively high, while when determined based on the key land cover types, it is much lower. This indicates intense land use on the one hand (e.g. forest areas differ not only in terms of habitat, but also in terms of the dominant species and age, constituting separate spatial microstructures). On the other hand, the high fragmentation of arable land complexes indicates that the wildlife and vegetation typical for agrocenoses may have been preserved.

- $\quad$ On the one hand, high-land fragmentation and the land cover spatial pattern should be treated as key characteristics of the landscape near Płock, but on the other, the tendency for simplification and homogenization of spatial structure within microregions and growing differences between them is an example of the more general process taking place in different regions of Poland (Solon 2007).

\section{Acknowledgement}

The data and analyses presented in this study were developed under grant No. N305 322135 of the Polish Ministry of Science \& Higher Education

\section{References}

Aaviksoo, K 1995, 'Simulating vegetation dynamics and land use in a mire landscape using a Markov model', Landscape and Urban Planning, vol. 31, pp. 129-142.

Benz, UC, Willhauck, PG \& Lingenfelder, M 2004, 'Multiresolution, rbject-oriented fuzzy analysis of remote sensing data for GIS-ready information', SPRS Journal of Photogrammetry \& Remote Sensing, vol. 58, 239-258.

Blaschke, T \& Hay, GJ 2001, 'Object-oriented image analysis and scale-space: theory and methods for modeling and evaluating multiscale landscape structures', International Archives of Photogrammetry and Remote Sensing, vol. 34, part 4/W5, pp. 22-29.
eCognition Developer 8.64.0 User Guide, 2010, Trimble Documentation, München, Germany.

Griffiths, GH, Lee, J \& Eversham, BC 2000, 'Landscape pattern and species richness; regional scale analysis from remote sensing', International Journal of Remote Sensing, vol. 21, pp. 2685-2704.

Gulinck, H, Múgica, M, de Lucio, JV \& Atauri, JA 2001, 'A framework for comparative landscape analysis and evaluation based on land cover data, with an application in the Madrid region (Spain)', Landscape and Urban Planning, vol. 55, pp. 257-270.

Hay, GJ, Niemann, KO \& Goodenough, DG 1997, 'Spatial 
thresholds, image-objects and upscaling: A multi-scale evaluation', Remote Sensing of Environment, vol. 62, pp. $1-19$.

Global Land Cover Facility 2011, Earth science data interface. Available from: http://glcfapp.glcf.umd.edu:8080/esdi/. [2011.10.10].

Lechnio, J 2005, 'Użytkowanie terenu w strefie oddziaływania PZM-P w okresie 1987-1999' [Land use in the zone of impact of the Plock Urban-Industrial Complex in the period 1987-1999] in Z problematyki funkcjonowania krajobrazów nizinnych [On the problems of functioning of the lowland landscapes], eds A Richling \& J Lechnio, WGSR UW, Warszawa, pp. 89-94.

Mander, U, Muller, F \& Wrbka, T 2005, 'Functional and structural landscape indicators: Upscaling and downscaling problems', Ecological Indicators, vol. 5, pp. 267-272.

McGarigal, K, Tagil, S \& Cushman, SA 2009, 'Surface metrics: an alternative to patch metrics for the quantification of landscape structure', Landscape Ecol., vol. 24, pp. 433-450.

Piorr, HP 2003, 'Environmental policy, agri-environmental indicators and landscape indicators', Agriculture, Ecosystems and Environment, vol. 98, pp. 17-33.

Richling, A\& Lechnio, J (eds) 2005, Z problematykifunkcjonowania krajobrazów nizinnych [On the problems of functioning of the lowland landscapes], WGSR UW, Warszawa.

Richling, A \& Lechnio, J 2012, 'Krajobraz jako system hierarchiczny' [Landscape as hierarchical system] in Model funkcjonalny systemu krajobrazowego [Functional model of the landscape system], eds A Richling \& J Lechnio, WGSR UW, Warszawa, pp. 9-29.

Richling, A, Malinowska, E \& Lechnio, J 2005, 'Typologia i regionalizacja terenów w strefie oddziaływania Płockiego Zespołu Miejsko-Przemysłowego'[Typology and regionalization terrain in the zone of influence of the Plock Urban-Industrial Complex] in Z problematyki funkcjonowania krajobrazów nizinnych [On the problems of functioning of the lowland landscapes], eds A Richling \& J Lechnio, WGSR UW, Warszawa, pp. 29-54.

Richling, A, Malinowska, E \& Szumacher, I 2012, 'Typologia i regionalizacja krajobrazu jako wyraz hierarchicznej struktury środowiska' [Typology and regionalization of landscape as an expression of the hierarchical structure of the environment] in Model funkcjonalny systemu krajobrazowego [Functional model of the landscape system], eds A Richling \& J Lechnio, WGSR UW, Warszawa, pp. 31-76.

Roo-Zielińska, E, Solon, J \& Degórski, M 2007, 'Ocena stanu i przekształceń środowiska przyrodniczego na podstawie wskaźników geobotanicznych, krajobrazowych i glebowych' [Assessment of the state and the transformation of the natural environment on the basis of geobotanic, landscape and soil indicators], IGiPZ PAN Monografie, vol. 9.

Solon, J 2002, 'Ocena różnorodności krajobrazu na podstawie analizy struktury przestrzennej roślinności' [Assessing the diversity of landscape based on an analysis of the spatial structure of vegetation], Prace Geograficzne, vol. 185.

Solon, J 2005, 'Struktura roślinności jako indykator stanu i funkcjonowania krajobrazu' [The structure of vegetation as an indicator of the status and functioning of the landscape] in Z problematyki funkcjonowania krajobrazów nizinnych [On the problems of the functioning of lowland landscapes], eds A Richling \& J Lechnio, WGSR UW, Warszawa, pp. 207-238.

Solon, J 2007, 'Wpływ środowiska na zróżnicowanie kierunków rozwoju obszarów wiejskich' [Impact of the environmental diversity on differentiation of rural development directions], Biuletyn KPZK, vol. 234, pp. 103-117.

Turner, MG 1989, 'Landscape ecology: the effect of pattern on process', Annual Review of Ecology and Systematics, vol. 20, pp. 171-197.

Turner, MG, O'Neill, RV, Gardner, RH \& Milne, BT 1989, 'Effects of changing spatial scale on the analysis of landscape pattern', Landscape Ecology, vol. 3, no. 3-4, pp. 153-162.

Uuemaa, E, Antrop, M, Roosaare, J, Marja, R \& Mander, U 2009, 'Landscape Metrics and Indices: An Overview of Their Use in Landscape Research', Living Reviews in Landscape Research, vol. 3, no. 1.

Walz, U 2011, 'Landscape structure, landscape metrics and biodiversity', Living Rev. Landscape Res., vol. 5, no. 3, pp. 5-35.

Wrbka, T, Reiter, K, Szerencsits, E, Niandl, P, Bartel, A, Schneider, W, Suppan, F \& Beissmann, H 1998, 'Landscape structure derived from satellite images as indicator for sustainable landuse' in Proceedings of the EARSeL Symposium on Operational Remote Sensing for Sustainable Development, Enschede [11-15 May 1998]. 